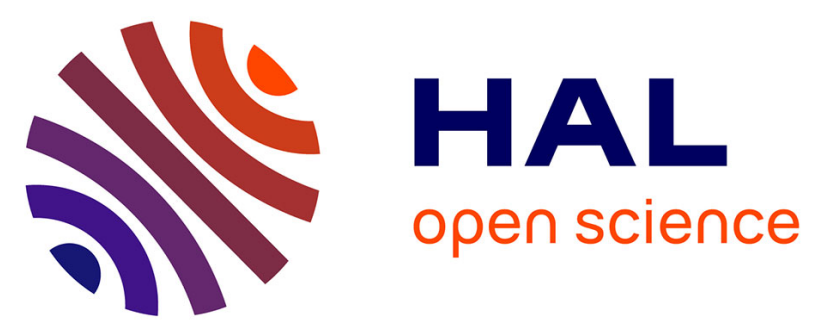

\title{
Transient self-potential anomalies associated with recent lava flows at Piton de la Fournaise volcano (Réunion Island, Indian Ocean)
}

\author{
Stéphanie Barde-Cabusson, G. Levieux, Jean-François Lénat, Anthony
} Finizola, André Revil, Marie Chaput, S. Dumont, Z. Duputel, A. Guy, L.

Mathieu, et al.

\section{To cite this version:}

Stéphanie Barde-Cabusson, G. Levieux, Jean-François Lénat, Anthony Finizola, André Revil, et al.. Transient self-potential anomalies associated with recent lava flows at Piton de la Fournaise volcano (Réunion Island, Indian Ocean). Journal of Volcanology and Geothermal Research, 2009, 187 (3-4), pp.158-166. 10.1016/j.jvolgeores.2009.09.003 . insu-00498414

\section{HAL Id: insu-00498414 https://hal-insu.archives-ouvertes.fr/insu-00498414}

Submitted on 22 May 2017

HAL is a multi-disciplinary open access archive for the deposit and dissemination of scientific research documents, whether they are published or not. The documents may come from teaching and research institutions in France or abroad, or from public or private research centers.
L'archive ouverte pluridisciplinaire HAL, est destinée au dépôt et à la diffusion de documents scientifiques de niveau recherche, publiés ou non, émanant des établissements d'enseignement et de recherche français ou étrangers, des laboratoires publics ou privés. 


\title{
Transient self-potential anomalies associated with recent lava flows at Piton de la Fournaise volcano (Réunion Island, Indian Ocean)
}

\author{
S. Barde-Cabusson ${ }^{a, *, 1}$, G. Levieux ${ }^{\mathrm{a}, \mathrm{b}}$, J.-F. Lénat ${ }^{\mathrm{a}}$, A. Finizola ${ }^{\mathrm{c}}$, A. Revil ${ }^{\mathrm{d}, \mathrm{e}}, \mathrm{M}$. Chaput ${ }^{\mathrm{a}}$, S. Dumont ${ }^{\mathrm{f}}$, \\ Z. Duputel ${ }^{f}$, A. Guy ${ }^{\text {f }}$, L. Mathieu ${ }^{a}$, S. Saumet ${ }^{a}$, F. Sorbadère ${ }^{a}$, M. Vieille ${ }^{\text {f }}$ \\ a Laboratoire Magmas et Volcans Univ. Blaise Pascal-CNRS-OPGC, 5 rue Kessler, Clermont-Ferrand, France \\ b IPGP, CNRS, UMR 7154, Paris, France \\ ' Laboratoire GéoSciences Réunion, Université de la Réunion, IPGP, CNRS, UMR 7154-Géologie des Systèmes Volcaniques, La Réunion, France \\ d Colorado School of Mines, Dept. of Geophysics, Golden, CO, USA \\ e CNRS-LGIT (UMR 5559), University of Savoie, Equipe Volcan, Le Bourget-du-Lac, France \\ ${ }^{\mathrm{f}}$ Ecole et Observatoire des Sciences de la Terre, Université Louis Pasteur, Strasbourg, France
}

\section{A B S T R A C T}

Self-potential signals are sensitive to various phenomena including ground water flow (streaming potential), thermal gradients (thermoelectric potential), and potentially rapid fluid disruption associated with vaporization of water. We describe transient self-potential anomalies observed over recent ( $<9$ years) lava flows at Piton de la Fournaise volcano (Reunion Island, Indian Ocean). Repeated self-potential measurements are used to determine the decay of the self-potential signals with time since the emplacement of a set of lava flow. We performed a $9 \mathrm{~km}-$ long self-potential profile in February 2004 in the Grand Brûlé area. This profile was repeated in July-August 2006. The second repetition of this profile crossed eight lava flows emplaced between 1998 and 2005 during seven eruptions of Piton de la Fournaise volcano. The self-potential data show clear positive anomalies (up to $330 \mathrm{mV}$ ) and spatially correlated with the presence of recent lava flows. The amplitude of the self-potential anomalies decreases exponentially with the age of the lava flows with a relaxation time of $\sim 44$ months. We explain these anomalies by the shallow convection of meteoric water and the associated streaming potential distribution but we cannot exclude possible contributions from the thermoelectric effect and the rapid fluid disruption mechanism. This field case evidences for the first time transient self-potential signals associated with recent volcanic deposits. It can be also a shallow analogue to understand the variation of self-potential signals in active geothermal areas and transient self-potential signals associated with dike intrusion at larger depths. The empirical equation we proposed can also be used to diagnose the cooling of recent lava flow on shield volcanoes.

\section{Introduction}

Self-potential signals refer to quasi-static electrical potential anomalies, usually measured at the ground surface of the Earth, that are associated with the occurrence of source current densities existing at depth (Sill, 1983; Corwin, 1997). One of the inherent problems associated with the interpretation of self-potential signals lies in the variety of source mechanisms in conductive media (Revil and Linde, 2006). For instance, self-potential signals can be generated by redox potentials associated with ore bodies or the metallic casing of boreholes or contaminant plumes that are rich in organic matter (Sato and Mooney, 1960; Minsley et al., 2007; Linde and Revil, 2007; Castermant

\footnotetext{
* Corresponding author. Dipartimento di Scienze della Terra, Università di Firenze, Via La Pira 4, 50121, Firenze, Italy. Tel.: +39 055 2757479; fax: +39 0552756242.

E-mail address: s.barde.cabusson@gmail.com (S. Barde-Cabusson).

${ }^{1}$ Present address: Dipartimento di Scienze della Terra, Università Degli Studi di Firenze, Italy.
}

et al., 2008). A second source of self-potential anomalies is the thermoelectric effect (Nourbehecht, 1963; Sill, 1983) that is associated directly with a gradient of the temperature affecting the chemical potential gradient of charge carriers (Revil, 1999; Revil and Linde, 2006). A third source is related to gradients of the chemical potential of the ionic charge carriers at constant temperature (MacInnes, 1961; Nourbehecht, 1963; Revil, 1999). A fourth source of self-potential signals is the streaming potential contribution related to the flow of the pore water relative to the mineral grain framework in saturated (Overbeek, 1952; Nourbehecht, 1963) and unsaturated conditions (Revil and Cerepi, 2004; Linde et al., 2007). A fifth potential contribution, called the rapid fluid disruption effect, has been also proposed by Johnston et al. (2001) based on previous works by Blanchard (1964) in non-porous media. However the experiments conducted by Johnston et al. (2001) were strongly criticized by Revil (2002) and were unable to prove the existence of a true self-potential signature of vaporization of the water phase. As explained by Revil (2002), this does not rule out this mechanism as being an additional contribution to self-potential signals. 
Because of the diversity of these sources, the self-potential method has been considered as a qualitative geophysical method for a long time since its discovery by Fox (1830). However, in the two last decades, quantitative interpretations of self-potential signals have been performed for various applications in hydrogeophysics (e.g., Trique et al., 2002; Rizzo et al., 2004) and volcanology (e.g., Ishido and Pritchett, 1999; Revil et al., 2003).

In the present work, we report two self-potential surveys carried out before and after the emplacement of lava flows at the Piton de la Fournaise volcano. These surveys show that positive self-potential anomalies are created above recent lava flows, which corresponds to very shallow thermal anomalies i.e. not related to deep hydrothermal roots. We show how these self-potential anomalies vanish over time as the lava flows cool down. On active volcanoes, when mapping perennial structures, fault zones or hydrothermal activity, this type of shallow transient self-potential anomalies can represent a spurious signal. On the other hand, lava flows thus provide natural, small-scale analogue models of the building and vanishing of thermal areas on volcanoes.

\section{Self-potential and thermal anomalies}

We start this paper by a quick review of the observations made in the literature regarding the correlations observed between selfpotential and thermal anomalies. Over the past few decades, selfpotential measurements have been extensively used to delineate shallow thermal anomalies over active volcanoes and geothermal fields. Examples of strong (>100 mV) positive self-potential anomalies unambiguously related to shallow thermal anomalies have been observed by Zohdy et al. (1973), Zablocki (1976), Anderson and Johnson (1979), Aubert et al. (1984), Lénat (1987), Nishida and Tomiya (1987), Matsushima et al. (1990), Malengreau et al. (1994), Lewicki et al. (2003), and Finizola et al. $(2003,2006)$ just to cite few of them. The case of positive self-potential anomalies associated with recent lava flows has been already reported on basaltic shield volcanoes by (Lénat 1987; Jackson and Kauahikaua, 1987). Usually these positive self-potential anomalies are interpreted as the surface signature of preferential pathways for the upflow of hydrothermal fluids of deep origin (Zablocki, 1976; Ishido et al., 1989; Lénat et al., 1998; Finizola et al., 2004). In some other cases, these anomalies can be associated with thermohydromechanical disturbances associated to magmatic intrusion emplacement at depth (Hashimoto and Tanaka, 1995; Revil et al., 2003) or shear and hydrofracturing (Moore and Glaser, 2007). A comprehensive modelling of the relationship between transient self-potential anomalies and hydromechanical disturbances has been provided recently by Crespy et al. (2008) in the laboratory and Legaz et al. (2009a) in the field.

However, hydrothermal fields are not always associated with large self-potential anomalies. Small anomalies $(<100 \mathrm{mV})$ were observed on the summit crater of Me-akan volcano (Hokkaido, Japan) in an area of intense fumarolic activity (temperature $>500{ }^{\circ} \mathrm{C}$ ) (Matsushima et al., 1990). Another example concerns the very small self-potential anomalies (few tens of $\mathrm{mV}$ ) observed on the summit crater floor of Esan volcano (Hokkaido) despite the presence of intense fumarolic activity (Nishida et al., 1996). Recent developments of the electrokinetic theory describing the occurrence of self-potential signals associated with the movement of the water phase predict that the streaming potential coupling coefficient decreases with the water saturation and is null at the irreducible water saturation (Revil et al., 2007). This explains also why dry steam does not produce selfpotential signals. In addition, the $\mathrm{pH}$ of the pore water plays a critical role in the occurrence of self-potential signals as illustrated by the observations made by Legaz et al. (2009b) at Inferno lake, Waimangu, New Zealand.

The positiveness of the self-potential anomalies associated with thermal anomalies is well-explained by the electrokinetic theory. The zeta potential, a key parameter describing electrokinetic effects, is negative. Basically, this means that the surface of the rock minerals is negatively charged. This charge is counterbalanced by positive mobile charges in a more external layer of the mineral. A fluid flow in the pore space (e.g. hydrothermal convecting water) carries these mobile charges downstream, thus making it positively charged (e.g., Overbeek, 1952; MacInnes, 1961; Revil, 2002). However, several cases of positive zeta potential have been reported in hydrothermal systems. Electrical surface potential of calcite, a secondary mineral often present in hydrothermal systems, can range from positive to negative values depending on $\mathrm{CO}_{2}$ partial pressure, $\mathrm{pH}$, and $\left[\mathrm{Ca}^{2+}\right]$ (Revil, 1995; Pokrovsky et al. 1999). Guichet et al. (2006) demonstrated the effect of calcite precipitation on the electrokinetic behaviour of sand samples. They found zeta potential ranging from -17 to $+8 \mathrm{mV}$ for $\mathrm{pH}$ ranging from 8.6 to 11.7 depending on the amount of precipitated calcite. A few cases of positive zeta potential in active hydrothermal fields are presented by Hase et al. (2003) and Aizawa et al. (2008). This means that in some few cases, negative self-potential signals can be observed in the flow direction.

The magnitude of self-potential signals is also controlled by the distribution of the electrical resistivity of the ground (e.g., Ishido, 2004), which can be strongly influenced by the temperature itself (Revil et al., 2002). Resistivity is also very dependent on the water content of the rock, which can change over time in a geothermal system because of liquid-vapour phase changes (for a field example see Legaz et al., 2009b). In their experiments on advancing boiling front in a porous medium, Moore and Glaser (2004) have shown that the streaming potential can increase by a factor of 2 to 50 by comparison with single phase flow. This enhancement could be due to the increase in the bulk resistivity of the material.

\section{Field survey}

The Piton de la Fournaise is located on the west side of Réunion Island in the Indian Ocean (Fig. 1). It is one of the most active volcanoes in the world. Since 1998, the activity of this shield volcano has been characterized by an average of three eruptions per year producing mostly lava flows. During the last decade or so, several lava flows have reached the coastal area in the depression called Grand Brûlé (Bachèlery, 1999; Peltier, 2007) (Fig. 1). These recent lava flows are well-individualized bodies and can therefore be easily identified over a basement formed by older cold lava flows. Older lava flows are also more or less invaded by tropical vegetation. In this area, the lava flows crossed a south north running road and sometimes reach the sea (Fig. 1). Because this road is the only connection in this part of the island, it was rebuilt after each event (Fig. 2).

We performed self-potential measurements along a $9 \mathrm{~km}$-long profile (Fig. 1). This profile is part of a larger dataset forming closed loops in this part of Réunion Island. We applied a closure correction along these loops to limit cumulative errors on such long profiles. A first dataset of self-potential measurements was acquired in February 2004 and repeated in July/August 2006, therefore with a time lapse of $\sim 31$ months. All the measurements were performed using non-polarizing $\mathrm{Cu} / \mathrm{CuSO}_{4}$ electrodes and a calibrated high impedance voltmeter ( $10 \mathrm{Mohm}$ ) with a sensitivity of $0.1 \mathrm{mV}$. During the measurements, the reference and moving electrodes were switched every few hundred meters in order to avoid the systematic error due to electrodes offset. We controlled the contact between the electrodes through the ground by checking the electric resistance before each measure point. As a rule of thumb, the electrical resistance between the two non-polarizing electrodes should be always ten times smaller than the internal impedance of the voltmeter (Corwin, 1997). The measured ground resistances were almost always smaller than $200 \mathrm{k} \Omega$. During the 2006 survey, 90\% of the data were below $100 \mathrm{k} \Omega$ and only $\sim 4 \%$ of the resistances reached values above $500 \mathrm{k} \Omega$. No correlation appeared between self-potential 


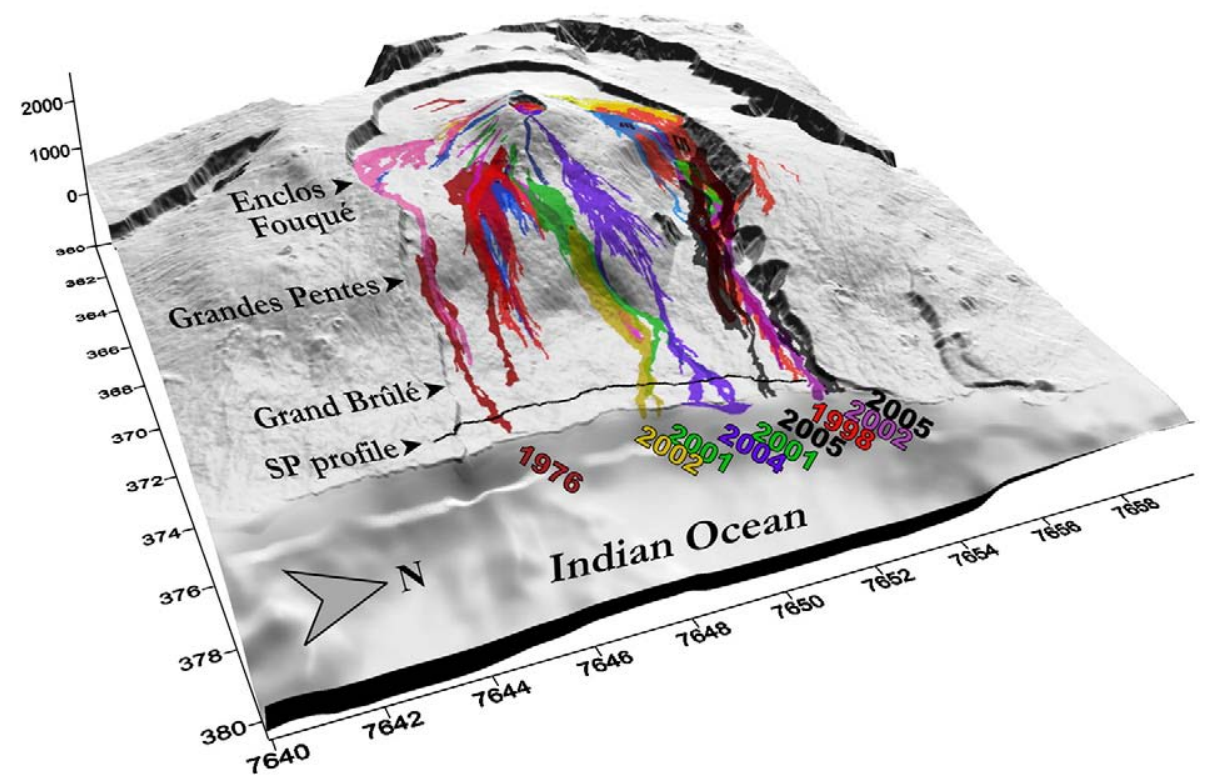

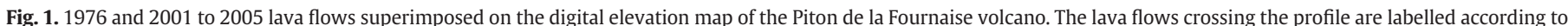

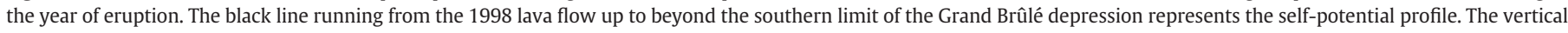
axis corresponds to the elevation (in $\mathrm{m}$ ) while the horizontal axes are expressed in UTM WGS84 coordinates (in km).

values and grounding resistances indicating that the measurements are reliable. The measurements were performed along the road, on soils not disturbed by the reconstruction of the road.

The first and second datasets were acquired with a spacing of $50 \mathrm{~m}$ and $20 \mathrm{~m}$, respectively. The location of the stations was determined using a handheld GPS receiver. The maximum divergence between the tracks of the two profiles $(\sim 20-50 \pm 10 \mathrm{~m})$ is located at the intersection of the road with the southern branch of the 2004 lava flow. Indeed, after the 2004 eruption the road was not rebuilt exactly along the same path. For the remainder of the profile, this deviation is however lower than $10 \mathrm{~m}$.

The northern and southern ends of the two profiles were located in "stable" areas in the sense that these areas were not subject to significant variations of the self-potential signal over time. The south reference is however located in an inhabited area which generates anthropic electromagnetic signals, and thus there are instabilities in the self-potential measurements. An offset of $99 \mathrm{mV}$ at the end of the second profile with respect to the former have been linearly distributed along the 2004 profile.

In addition to self-potential measurements, it is also quite customary to collect $\mathrm{CO}_{2}$ and temperature measurements to assess the preferential fluid flow pathways in the ground (e.g., Finizola et al., 2003, 2004, 2006). On Piton de la Fournaise volcano, in the Grand Brûlé area, the aa and pahoehoe lava flows are highly fractured. Owing to this high porosity, air circulation in the first tens of $\mathrm{cm}$ in the ground can be strong and irregular which makes soil temperature and gas measurement poorly

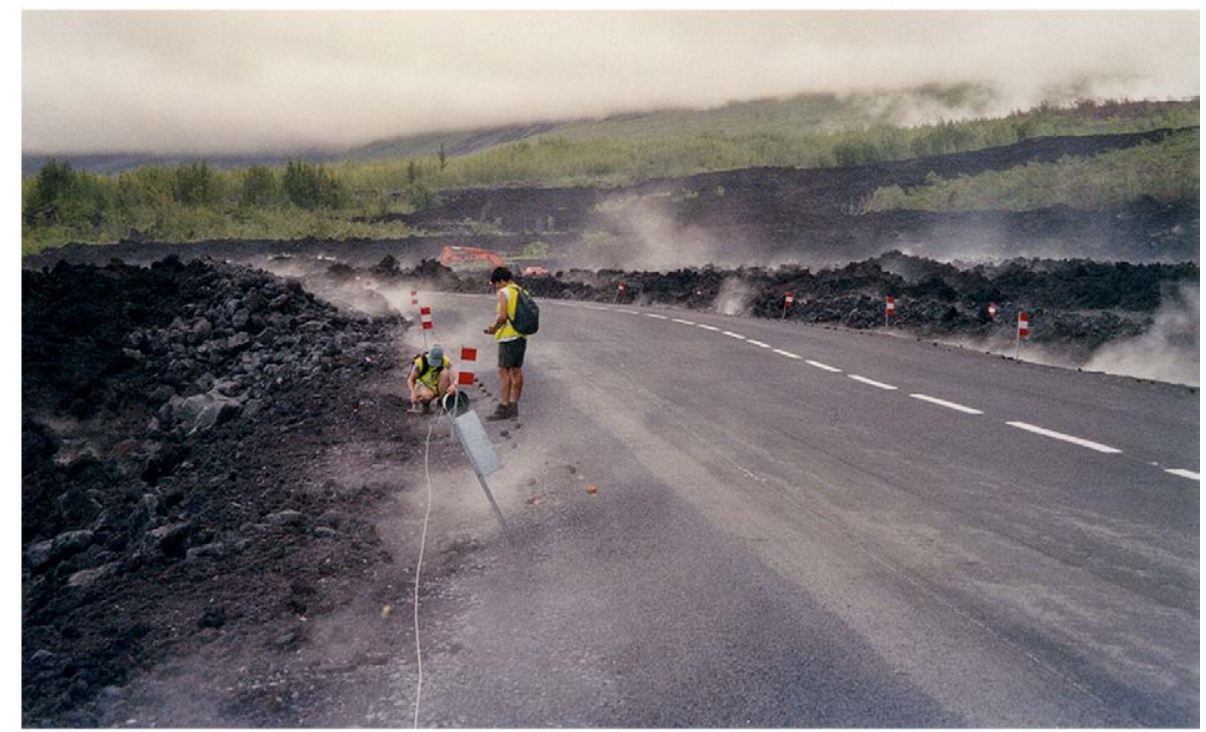

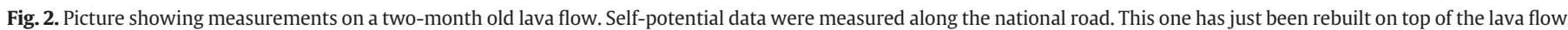
The water vapour field on the lava flow is due to the heating of the meteoric water that percolates through the still hot lava flow. 
reliable. Consequently, during the surveys presented in this study, no temperature measurements were performed.

\section{Distribution of recent lava flows}

\subsection{Description of the lava flows}

Since 1976 and until the 2006 survey, the road has been crossed ten times by lava flows, during seven different eruptions. The map of these lava flows is shown in Fig. 1. The self-potential profiles presented below follow the road and are intersected, from south to north, by: (1) the $1976 \mathrm{LF}$ (LF stands for lava flow hereinafter), (2) the November 2002 LF, (3) the southern branch of June 2001 LF buried under the 2002 LF, (4) the southern branch of August 2004 LF, (5) the northern branch of August 2004 LF, (6) the northern branch of June 2001 LF buried under the northern branch of August 2004 LF, (7) the southern branch of February 2005 LF, and finally (8) the 1998 LF which did not cross the road but stopped less than $4 \mathrm{~m}$ away from it. The January 2002 LF, and the northern branch of February 2005 LF, crossed the road at the northern end of the Grand Brûlé in an area not covered by the 2004 survey; this area could therefore not be compared (see Fig. 3).

The ages and known characteristics of the lava flows at the time of the surveys are reported in Table 1. Taking into account the age of the lava flows, the self-potential measurements were performed 18 months to 96 months ( 8 years) after their emplacements. The 1976 lava flow is not associated with a measurable self-potential anomaly. It can therefore be regarded as an end-member. On another hand, although the self-potential profiles run a few meters away from the tip of the 1998 lava flow, a clear self-potential signal was observed in 2004 and has virtually vanished in 2006. We have therefore also considered the case of this lava flow, even if the self-potential profiles did not directly cross it.

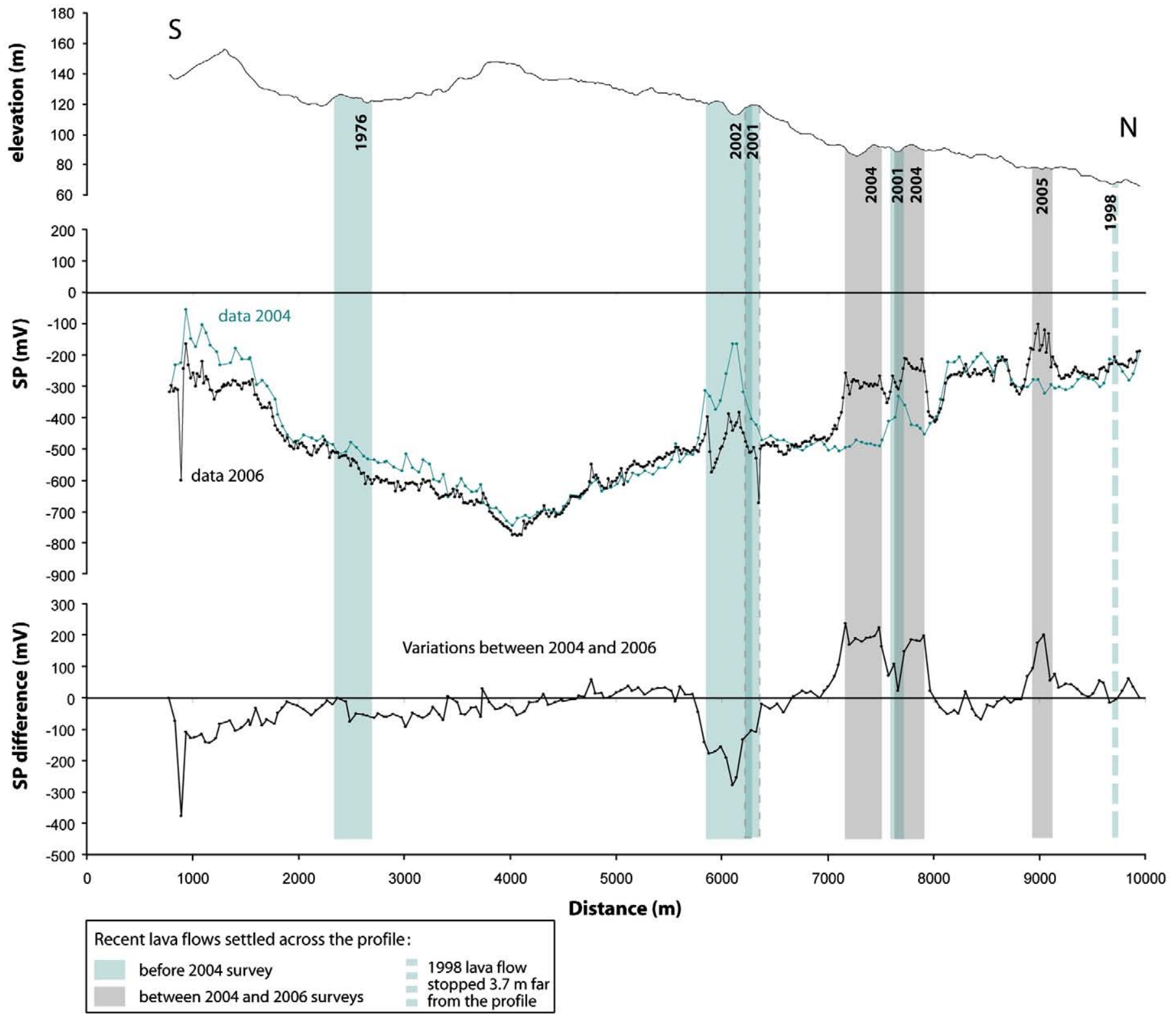

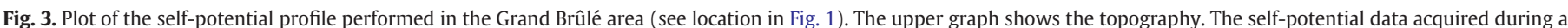

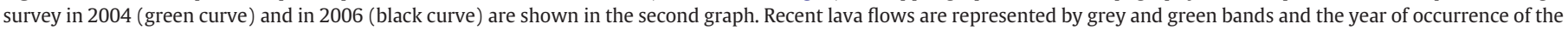

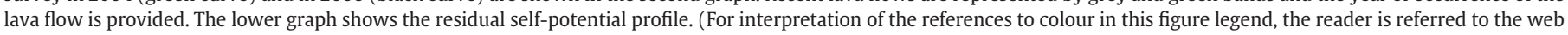
version of this article.) 
Table 1

Characteristics of the lava flows crossed during the surveys performed in 2004 and 2006, from south to north. The name of the lava flow comprised the date of its formation (month-year) plus an indication for the branch if several branches co-exist. SB and NB stand for south and north branches, respectively. The width of the lava flow is given along the self-potential surveys. The age of the lava flow is given at the time of the 2006 survey.

\begin{tabular}{llllll}
\hline Lava flow & $\begin{array}{l}\text { Width } \\
(\mathrm{m})\end{array}$ & Flow type & $\begin{array}{l}\text { Age } \\
(\mathrm{months})\end{array}$ & $\begin{array}{l}\delta \varphi \\
(\mathrm{mV}) \\
02 / 2004\end{array}$ & $\begin{array}{l}\delta \varphi \\
(\mathrm{mV}) \\
07-08 / 2006\end{array}$ \\
\hline $11-2002$ & 470 & aa & 45 & 335 & 115 \\
$8-2004-\mathrm{SB}$ & 350 & pahoehoe & 24 & - & 150 \\
$8-2004-\mathrm{NB}$ & 300 & pahoehoe & 24 & - & 210 \\
$6-2001-\mathrm{NB}$ & 120 & aa & 61 & 141 & - \\
$2-2005-\mathrm{SB}$ & 200 & aa & 18 & - & 180 \\
$3-1998$ & 0 & pahoehoe & 100 & 84 & 0 \\
$1-2002$ & 200 & aa & 55 & - & 100 \\
$2-2005-\mathrm{NB}$ & 400 & aa & 18 & - & 190 \\
\hline
\end{tabular}

\subsection{Cooling processes of lava flows}

Several processes contribute to the cooling of lava flows. For newly exposed lava flows, most of the heat is lost by radiation (Head and Wilson, 1986; Keszthelyi and Denlinger, 1996; Harris and Rowland, 2001). However, Keszthelyi et al. (2003) showed that the heat extracted by the convection of the atmosphere (i.e., the wind) is also a major component of the cooling. The thermal conductivity of the substratum is always higher than the thermal conductivity of the air so that conductive heat loss through the base is also very significant (Keszthelyi, 1995; Harris et al., 1998). At Piton de la Fournaise volcano, the lava flows are aa or pahoehoe flows with variable thickness and temperatures at the vent of about $1150{ }^{\circ} \mathrm{C}$ (e.g., Lénat et al., 1989). After their emplacement, the lava flows have usually large porosity created by thermal fractures, vesicles, and vertical heterogeneities (e.g., brecciated at the top and bottom of aa flows). Therefore additional cooling occurred also with the transport of the heat due to the air circulation through the network of fractures. It should be pointed out that, in the case of Piton de la Fournaise, the reconstruction of the road after an eruption implies that the surface of the lava flows is reworked and its thickness is slightly reduced. However, in a tropical context like on Reunion Island, the most efficient process of the cooling of the lava flow is percolation of the meteoric water through the system and free convection of the ground water inside and around the lava flow. The water vapour shown on Fig. 2 very well illustrates this phenomenon. On this part of the volcano, the annual rainfall is from 5 to $6 \mathrm{~m}_{\text {year }}{ }^{-1}$, which is a very high value in terms of rainfall (http://www.meteo.fr/temps/domtom/La_Reunion/ atlas_clim/essai2.htm).

\section{Observations and interpretations}

\subsection{Self-potential anomalies associated with lava flows}

The overall surveys show a good reproducibility showing a global V-shape of the self-potential signals along the profile (Fig. 3). The general self-potential/elevation relationship (Fig. 4) reveals a clear superimposition of two phenomenon: (1) a deep one extending across all the profile with a general negative linear gradient of $-7 \mathrm{mV} / \mathrm{m}$ related with the general hydrogeological context of the Grand Brûlé area, and (2) a shallow one, with positive anomalies whose lateral extension is clearly related with the recent lava flows. Such a superimposition in the self-potential signals of hydrogeological and hydrothermal information dealing with different depth has been already described on other volcanoes (Finizola et al., 2003; Revil et al., 2004). In our study case, the wavelength of these positive selfpotential anomalies is not related to the depth of the convective cells (or lava thickness) but directly to the width of the lava flow crossed by the self-potential profile (see Fig. 3).

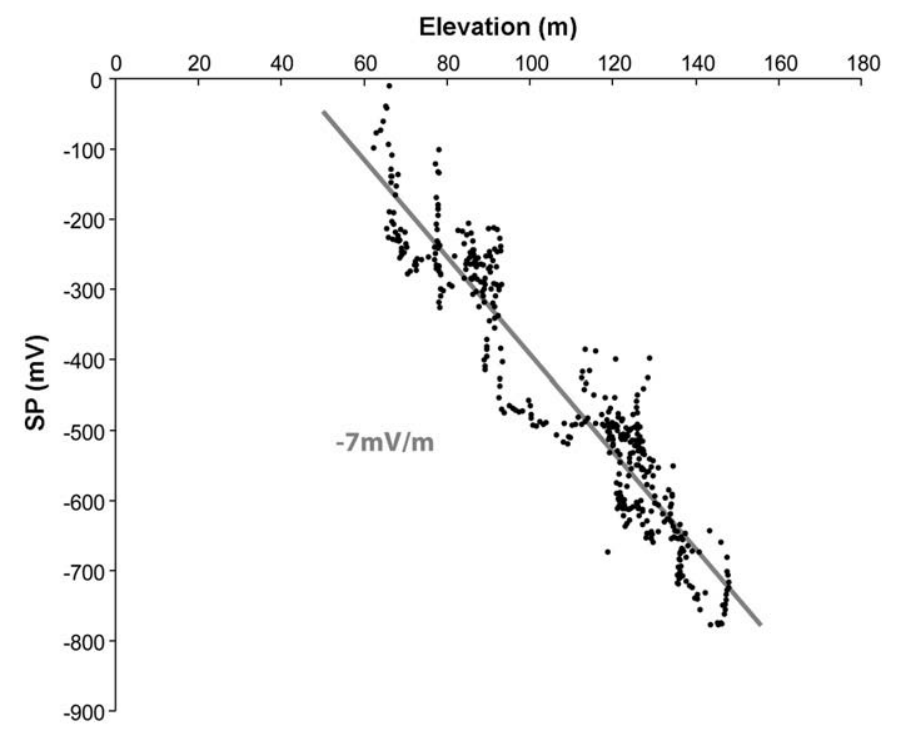

Fig. 4. Plot of the self-potential data as a function of the elevation for the 2006 dataset. A global trend illustrates the correlation between self-potential and elevation in the Grand Brûlé area. The self-potential/elevation gradient is $-7 \mathrm{mV} \mathrm{m}^{-1}$. On this general trend, there is a superimposition of shorter wavelength, positive, anomalies related to the different recent lava flows.

In the southern half of the Grand Brûlé, at a wide scale, the selfpotential profiles display a very similar trend from one survey to the other. Small differences appear to be randomly distributed with an amplitude of $\pm 50 \mathrm{mV}$. However, the similar trend for both surveys indicates the stability of the overall polarization process at the scale of the structure. This trend defines a baseline on the whole profile, which can be used in turn to define the occurrence of self-potential anomalies (see insert in Fig. 5).

In the northern half of the Grand Brûlé, the positive anomalies are spatially correlated with the presence of lava flows emplaced between 1998 and 2005. They have amplitudes amounting tens to hundreds of millivolts (Fig. 3). Between the two self-potential anomalies related to the 2004 and 2005 lava flows, the two self-potential profiles form wellsuperimposed crenellations over $800 \mathrm{~m}$ and rising up to $\sim 120 \mathrm{mV}$ above the baseline. This positive self-potential anomaly is not correlated to the presence of a recent lava flow and its origin remains unclear.

The 2004 survey shows positive anomalies located on the lava flows which have crossed the Grand Brûlé road between 1998 and 2004. The 2006 survey shows new anomalies related to the 2004 and 2005 lava flows and allows us to follow the evolution of the anomalies detected in 2004.

The 1998 lava flow is a particular case as it does not cross the profile. It stopped less than $4 \mathrm{~m}$ away from the road and thus from the self-potential profiles. However, the 2004 survey shows a slight positive anomaly $(+84 \mathrm{mV})$. Although this anomaly is not directly measured on the flow, but a few meters away from its tip, it is also linked to the lava flow. Indeed, we observed on the other recent lava flows crossed during the survey that the self-potential anomalies extend beyond the limits of the flow itself, sometimes for a distance of more than $100 \mathrm{~m}$. This suggests that the emplacement of the hot lava flow induces perturbations of the electrical behaviour in the basement in the vicinity of the flow.

\subsection{Evolution of the self-potential anomalies}

Fig. 3 shows the difference between the self-potential signals of the two surveys. We call this difference the residual self-potential profile. It exhibits negative anomalies above the 2002 and 2001 lava flows (i.e. decrease of the anomaly amplitude between the two 


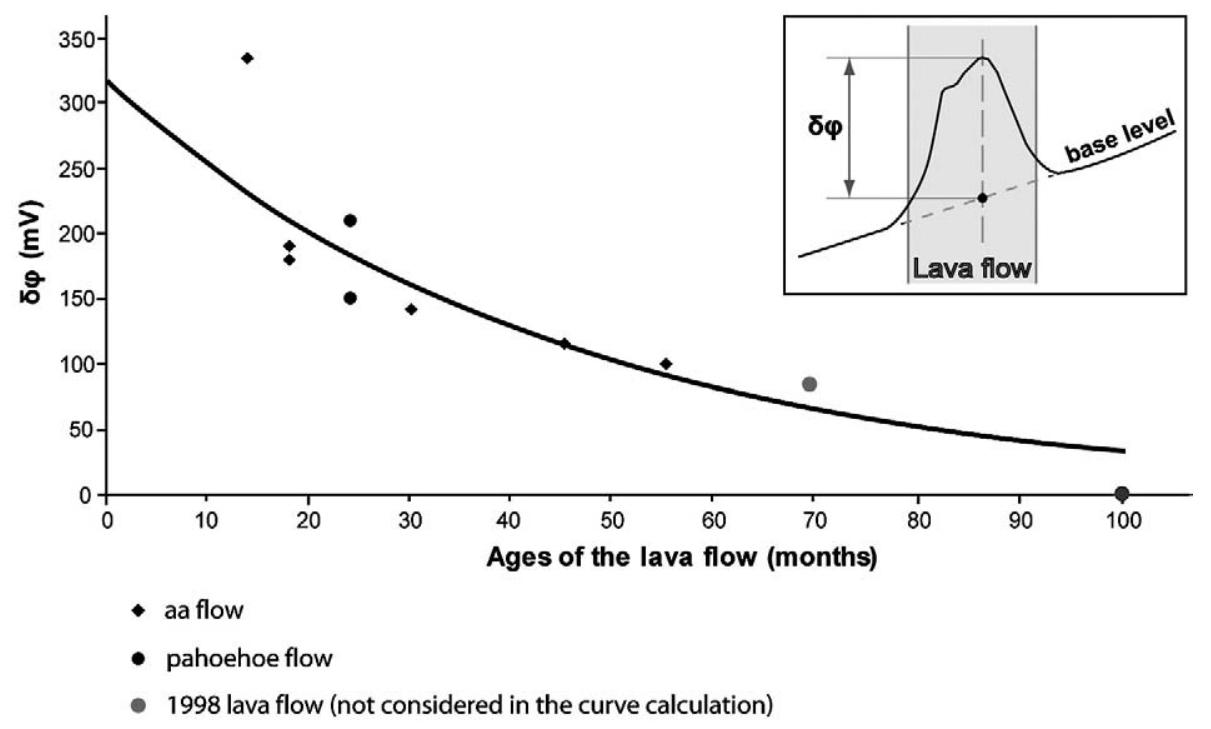

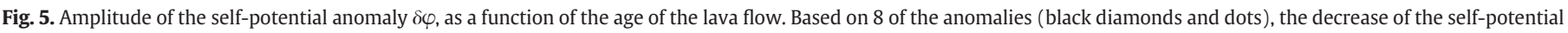

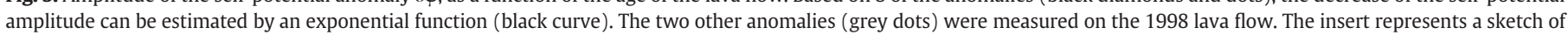
the method used to determine $\delta \varphi$.

surveys). This is not directly visible for 2001 lava flow which is buried under other lava flows. The residual displays positive anomalies where new lava flows were emplaced between the two surveys, as for the 2004 and 2005 lava flows.

We have quantified the amplitude of the anomalies as a function of the time since their emplacement (Fig. 5). Table 1 and Fig. 5 show amplitudes of the self-potential anomalies for each flow and for both surveys, illustrating the decrease of the self-potential signal with time, on cooling lava flows. All the recent lava flows (from 1998 to 2006) crossing the road are represented with measurements from both surveys. A regression has been traced based on 8 of the 10 anomalies, the two others being related to the 1998 lava flow which did not cross the road (the two grey dots on Fig. 5). For the period considered (55 months), the self-potential amplitude decrease is well described by a decreasing exponential:

$\delta \phi(t)=\delta \phi_{0} \exp (-t / \tau)$

where $\delta \varphi(t)$ is the intensity of the self-potential anomaly at time $t$ after the emplacement of the lava flow, $\delta \varphi_{0}=317 \mathrm{mV}$ represents the magnitude of the self-potential anomaly just after the emplacement of a lava flow, and $\tau=44$ months is the relaxation time of the duration of the self-potential anomaly. This characteristic time is probably equal to the characteristic time of the cooling process of the lava flow. The correlation coefficient of the fit between the data and Eq. (1) is $R^{2}=0.74$.

This new concept of self-potential decay time constant as the lava flow cool could be investigated more closely; in particular the interrelation between temperature, self-potential, and fluid flow. Temperature of a solidified lava flow is not an easy parameter to measure due to the characteristics of the surface topography. Contrary to some other volcanoes (Aubert et al., 2007), shallow vertical thermal gradient cannot be measured because aa lava flows prevent us from making good measurements due to the important air cooling at shallow depth, and pahoehoe lava flows do not allow taking measurements below the surface topography. Anyway, temperature inside the lava flow could be considered as a parameter deduced from the positive self-potential anomalies. Considering that the positive self-potential anomalies are generated by the drag of positive charges toward the surface, the vanishing of positive self-potential anomalies would mean that after about 44 months (3-4 years) heat supplied by these lava flows is not enough to mobilize shallow ground water flow.

Another important fact to consider is that the exponential function has been defined from several lava flows of different age but with only 2 periods of data acquisition (February 2004 and July-August 2006). The function has been defined thanks to 8 data points ( 2 from 2004 and 6 from 2006). Although a general decay of the amplitude of selfpotential signal as function of time is obvious, only a permanent monitoring system could help in discriminating long term selfpotential decay due to lava flow cooling from short term self-potential increase due to rain water supply inside the system. This exponential relationship between the decrease of the self-potential signal and the age of a lava flow must therefore be taken with care because it does not differentiate lava flows with different thicknesses, width, and morphology. Once the causative source of these elf-potential signals will be identified, numerical modelling will be used to perform a sensitivity analysis of this problem.

\subsection{Origin of the self-potential anomalies above lava flows}

Three mechanisms can potentially explain the occurrence of selfpotential anomalies associated with recent lava flow. They are the streaming current associated with the flow of the pore water, even in unsaturated conditions, the thermoelectric effect, and the rapid fluid disruption mechanism associated with the vaporization of the water phase. In the present section, we discuss these three mechanisms.

The streaming current is generated by the relative displacement between the pore water and the mineral surface and electrical double layer polarization at the surface of the minerals (e.g. Overbeek, 1952; MacInnes, 1961; Revil et al., 2002). The resulting macroscopic electrical field associated with the flow of the pore water is called the streaming potential. In volcanic rocks, at $\mathrm{pH}=7$, the flow of the pore water produces a positive potential in the flow direction. In saturated conditions, a temperature gradient can generate an electrokinetic effect by triggering the convection of the pore fluid at a Rayleigh number greater than a critical value corresponding to the onset of thermal convection of the pore water (Revil and Pezard, 1998; Revil et al., 1999; Revil, 2002). Another consequence of temperature increase which, as well, involves electrokinetic coupling is the differential expansion between the pore fluid and the grains forming 


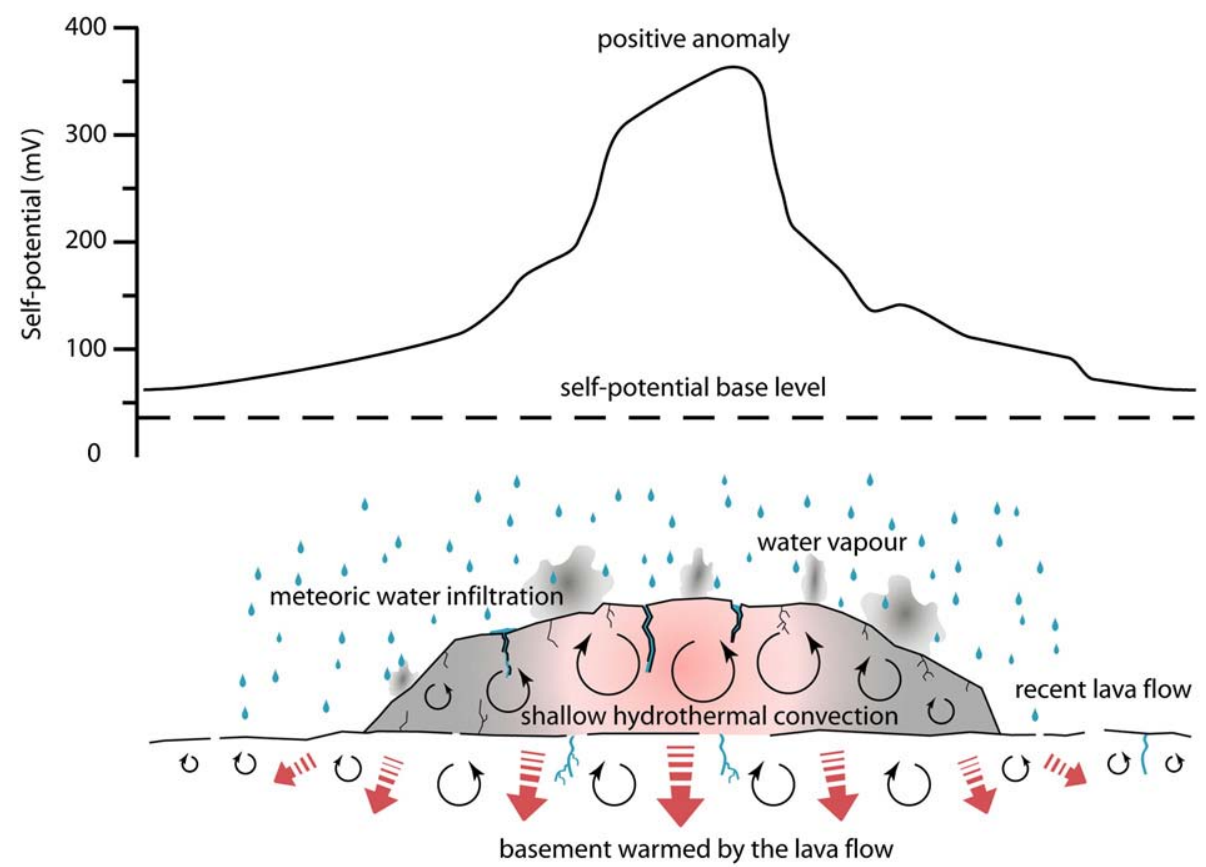

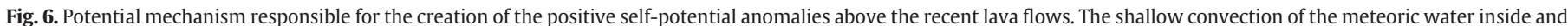
around the hot lava flow is responsible for a self-potential anomaly of electrokinetic nature.

the mineral framework (Revil et al., 2003). Can the streaming current contribution explain the observed self-potential signals? In our study, in the presence of a hot lava flow, the fluid circulation is modified. Rain water penetrates inside the lava flow, is heated and a shallow convective system is thus established even in unsaturated conditions, not only in the lava flow but also in its vicinity (Fig. 6).

The thermoelectric contribution to self-potential signals corresponds to the effect of the temperature upon the chemical potential of an electrolyte (see Revil, 1999; Revil and Linde, 2006). A temperature gradient is responsible for an electrical field even if the concentration of the charge carriers is initially uniform. The generation of an electrical field due to the presence of a temperature gradient in water saturated porous materials has been investigated experimentally by Nourbehecht (1963), Corwin and Hoover (1979), and Fitterman and Corwin (1982). Experimental data from Corwin and Hoover (1979) give a thermoelectric coupling coefficient ranging from 0.1 to $1.5 \mathrm{mV}^{\circ} \mathrm{C}^{-1}$. For volcanic rocks the average value is around $0.2 \mathrm{mV}^{\circ} \mathrm{C}^{-1}$. However, it is not clear if these data have been properly corrected for the temperature difference of the Nernst potential of the electrodes and if other mechanisms (the electrokinetic effect discussed above for instance) do not contribute to the measured electrical field. In the field, the case studies reported by Goldstein et al. (1989) or Finizola et al. (2003) for instance seem to confirm that the streaming current is the dominating mechanism (see also Matsushima et al., 1990 and Nishida et al., 1996). In the case of the self-potential signals associated with the emplacement of recent lava flows, the thermoelectric contribution can be potentially very strong. The sensitivity coefficient discussed above $\left(0.2 \mathrm{mV}^{\circ} \mathrm{C}^{-1}\right)$ could clearly explain the magnitude and polarity of the observed self-potential signals associated with recent lava flows.

A third potential contribution, called the rapid fluid disruption effect, corresponds to the vaporization of water when in contact with hot rocks. This has been also proposed by Johnston et al. (2001) based on previous works by Blanchard (1964). However the experiments conducted by Johnston et al. (2001) did not prove the existence of this mechanism as discussed by Revil (2002). Johnston et al. (2001) did not also perform temperature correction for their electrodes during their experiments. Nevertheless, this does not rule out this mechanism as being an additional contribution to self-potential signals and the rapid fluid disruption mechanism should be investigated, its physics rigorously established, and tested both in the laboratory and in the field.

\section{Concluding statements}

Two repeated self-potential surveys at Piton de la Fournaise volcano show a clear correlation between positive self-potential anomalies and recent lava flows. We hypothesize that these anomalies are associated with shallow convection of the meteoric water inside and around the hot lava flow but we cannot exclude the thermoelectric effect and the rapid fluid disruption mechanisms as being important if not dominant.

Such shallow source of self-potential associated with the emplacement of recent lava flows has never been described in literature to the best of our knowledge. It has to be taken into account when interpreting self-potential data on active volcanoes. The case of these recent lava flows can indeed be considered as a small-scale analogue of thermal perturbations on volcanoes such as those induced by magma intrusions. It could be interesting to carry out a complete 4D study of a lava flow, including self-potential, geometry of the flow, temperature, resistivity, condensation in the flow, and pluviometry measurements. This could help to progress in understanding the contribution of the different parameters and of the different effects (thermoelectric, electrokinetic, and rapid fluid disruption), to self-potential signal. This could be useful to build models on the generation of self-potential signal and its evolution with time.

\section{Acknowledgments}

The 2004 field work was supported by the "Programme d'évaluation du potentiel Géothermique de la Réunion" (financed by the Réunion Region) and by the French ANR project VOLCARISK (contract \#06-CATT-013-04). We are particularly grateful to Benoit Fragnol and Frédéric Lorion for their help during the field work. We also thank Thierry Payet from the Office National des Forêts for his 
support. We thank Professor Jürgen W. Neuberg and two anonymous referees for helpful comments.

\section{References}

Aizawa, K., Uyeshima, M., Nogami, K., 2008. Zeta potential estimation of volcanic rocks on 11 island arc-type volcanoes in Japan: implication for the generation of local self-potential anomalies. J. Geophys. Res. 113, B02201. doi:10.1029/2007JB005058

Anderson, L.A., Johnson, G.R., 1979. Some observations of the self-potential effect in geothermal areas in Hawaii and Nevada. Geotherm. Resourc. Council Transact. 2, 9-12.

Aubert, M., Auby, R., Bourley, F., Bourley, Y., 1984. Contribution à la surveillance de l'activité de l'Etna à partir de l'étude des zones fumeroliennes. Bull. Volcanol. 47, $1039-1050$.

Aubert, M., Diliberto, S., Finizola, A., Chébli, Y., 2007. Double origin of hydrothermal convective flux variations in the Fossa of Vulcano (Italy). Bull. Volcanol.. doi:10.1007 s00445-007-0165-y

Bachèlery, P., 1999. Le fonctionnement des volcans boucliers. Exemple des volcans de la Réunion et de la Grande Comore. Mémoire d'Habilitation à Diriger des Recherches Université de la Réunion, France.

Blanchard, D.C., 1964. Charge separation from saline drops on hot surfaces. Nature 201, 1164-1166.

Castermant, J., Mendonça, C.A., Revil, A., Trolard, F., Bourrié, G., Linde, N., 2008. Redox potential distribution inferred from self-potential measurements during the corrosion of a burden metallic body. Geophys. Prospect. 56, 269-282. doi:10.1111/j.13652478.2007.00675.x.

Corwin, R.F., 1997. The self-potential method for environmental and engineering applications: geotechnical and environmental geophysics. In: Ward, H. (Ed.) Investigations in Geophysics: Soc. Expl. Geophys., vol. 5, p. 1.

Corwin, R.F., Hoover, D.B., 1979. The self-potential method in geothermal exploration. Geophysics 44 (2), 226-245.

Crespy, A., Revil, A., Linde, N., Byrdina, S., Jardani, A., Bolève, A., Henry, P., 2008. Detection and localization of hydromechanical disturbances in a sandbox using the self-potential method. J. Geophys. Res. 113, B01205. doi:10.1029/2007JB005042.

Finizola, A., Sortino, F. Lénat, J.-F., Aubert, M., Ripepe, M., Valenza, M., 2003. The summit hydrothermal system of Stromboli: new insights from self-potential, temperature, $\mathrm{CO} 2$ and fumarolic fluid measurements - structural and monitoring implications. Bull. Volcanol. 65, 486-504. doi:10.1007/s00445-003-0276-z.

Finizola, A., Lénat, J.-F., Macedo, O., Ramos, D., Thouret, J.-C., Sortino, F., 2004. Fluid circulation and structural discontinuities inside Misti volcano (Peru) inferred from self-potential measurements. J. Volcanol. Geotherm. Res. 135, 343-360.

Finizola, A., Revil, A., Rizzo, E., Piscitelli, S., Ricci, T., Morin, J., Angeletti, B., Mocochain, L, Sortino, F., 2006. Hydrogeological insights at Stromboli volcano (Italy) from geoelectrical, temperature, and $\mathrm{CO} 2$ soil degassing investigations. Geophys. Res. Lett. 33, L17304. doi:10.1029/2006GL026842.

Fitterman, D.V., Corwin, R.F., 1982. Inversion of self-potential data from the Cerro Prieto geothermal field, Mexico. Geophysics 47, 938-945.

Fox, R.W., 1830. On the electromagnetic properties of metalliferous veins in the mines of Cornwall. Philos. T. Roy. Soc. 120, 399-414.

Goldstein, N.E., Halfman, S., Corwin, R.F., Martinez, J., 1989. Self-potential anomaly changes at the East Mesa and Cerro Prieto geothermal fields. 14th Workshop on Geothermal Reservoir Engineering, Stanford University, Stanford, California, January 24-26th, 1989, SGP-TR-122.

Guichet, X., Jouniaux, L., Catel, N., 2006. Modification of streaming potential by precipitation of calcite in a sand-water system: laboratory measurements in the $\mathrm{pH}$ range from 4 to 12 . Geophys. J. Int. 166, 445-460.

Harris, A.J.L., Rowland, S.K., 2001. FLOWGO: a kinematic thermo-rheological model for lava flowing in a channel. Bull. Volcanol. 63, 20-44.

Harris, A.J.L., Flynn, L.P., Keszthelyi, L., Mouginis-Mark, P.J., Rowland, S.K., Resing, J.A., 1998 Calculation of lava effusion rates from Landsat TM data. Bull. Volcanol. 60, 52-71.

Hase, H., Ishido, T., Takakura, S., Hashimoto, T., Sato, K., Tanaka, Y., 2003. $\zeta$ potential measurement of volcanic rocks from Aso caldera. Geophys. Res. Lett. 30 (23), 2210 doi:10.1029/2003GL018694.

Hashimoto, T., Tanaka, Y., 1995. A large self-potential anomaly at Unzen volcano, Shimabara Peninsula Kyushu Island. Japan. Geophys. Res. Lett. 22, 191-194.

Head, J.W., Wilson, L., 1986. Volcanic processes and landforms of Venus - theory, predictions, and observations. J. Geophys. Res. 91, 9407-9446.

Ishido, T., 2004. Electrokinetic mechanism for the "W"-shaped self-potential profile on volcanoes. Geophys. Res. Lett. 31, L15616. doi:10.1029/2004GL020409.

Ishido, T., Pritchett, J.W., 1999. Numerical simulation of electrokinetic potentials associated with subsurface fluid flow. J. Geophys. Res. 104, 15247-15259.

Ishido, T., Kikuchi, T., Sugihara, M., 1989. Mapping thermally driven upflows by the selfpotential method, in Hydrogeological Regimes and Their Subsurface Therma Effects. Geophys. Monogr. Ser., 47 (IUGG vol. 2), edited by A. E. Beck et al.: 151-158, AGU, Washington, D. C

Jackson, D.B., Kauahikaua, J., 1987. Regional self-potential anomalies at Kilauea volcano. Volcanism in Hawaii: USGS. Prof. Pap., vol. 1350, pp. 947-959. chapter 40.

Johnston, M.J.S., Byerlee, J.D., Lockner, D., 2001. Rapid fluid disruption: a source for selfpotential anomalies. J. Geophys. Res. 107. doi:10.1029/2001JB000788.

Keszthelyi, L., 1995. Measurements of the cooling at the base of pahoehoe flows. Geophys. Res. Lett. 22, 2195-2198.

Keszthelyi, L., Denlinger, R., 1996. The initial cooling of pahoehoe flow lobes. Bull Volcanol. 58, 5-18.

Keszthelyi, L., Harris, A.J.L., Dehn, J., 2003. Observations of the effect of wind on the cooling of active lava flows. Geophys. Res. Lett. 30 (19), 1989. doi:10.1029/2003GL017994.
Legaz, A., Revil, A., Roux, P., Vandemeulebrouck, J., Gouédard, P., Hurst, T., Bolève, A., 2009a. Self-potential and passive seismic monitoring of hydrothermal activity: a case study at Iodine Pool, Waimangu geothermal valley, New Zealand. J. Volcanol. Geotherm. Res. 179 (1-2), 11-18.

Legaz, A., Vandemeulebrouck, J., Revil, A., Kemna, A., Hurst, A.W., Reeves, R., Papasin, R. 2009b. A case study of resistivity and self-potential signatures of hydrothermal instabilities, Inferno Crater Lake, Waimangu, New Zealand. Geophys. Res. Lett. 36, L12306. doi:10.1029/2009GL037573.

Lénat, J.-F., 1987. Structure et dynamique interne d'un volcan basaltique intraplaque océanique: Le Piton de la Fournaise (île de la Réunion). Thèse de doctorat ès Sciences (Ph.D.) Univ. Blaise Pascal, Clermont-Ferrand, France.

Lénat, J.-F., Bachélery, P., Bonneville, A., Tarits, P., Cheminée, J.-L., Delorme, H., 1989. The December 4, 1983 to February 18, 1984 eruption of Piton de la Fournaise (La Réunion, Indian Ocean): description and interpretation. J. Volcanol. Geotherm. Res. 36, 87-112.

Lénat, J.-F., Robineau, B., Durand, S., Bachélery, P., 1998. Etude de la zone sommitale du volcan Karthala (Grande Comore) par polarisation spontanée. C. R. Acad. Sci. 327, 781-788.

Lewicki, J.-L., Connor, C., St-Amand, K., Stix, J., Spinner, W., 2003. Self-potential, soil CO2 flux, and temperature on Masaya volcano, Nicaragua. Geophys. Res. Lett. 30 (15), 1-4. doi:10.1029/2003GL017731.

Linde, N., Revil, A., 2007. Inverting residual self-potential data for redox potentials of contaminant plumes. Geophys. Res. Lett. 34, L14302. doi:10.1029/2007GL030084.

Linde, N., Jougnot, D., Revil, A., Matthaï, S.K., Arora, T., Renard, D., Doussan, C., 2007. Streaming current generation in two-phase flow conditions. Geophys. Res. Lett. 34 (3), L03306. doi:10.1029/2006GL028878.

MacInnes, D.A., 1961. The Principles of Electrochemistry. Reinhold Publishing Company, Dover Publications, New York. 1961, 478 pp.

Malengreau, B., Lénat, J.F., Bonneville, A., 1994. Cartographie et surveillance temporelle des anomalies de Polarisation Spontanée (PS) sur le Piton de la Fournaise. Bull. Soc. Géol. Fr. 165, 221-232.

Matsushima, N., Michiwaki, M., Okazaki, N., Ichikawa, N., Takagi, A., Nishida, Y., Mori, H.Y., 1990. Self-potential study in volcanic areas - Usu, Hokkaido Komaga-take and Meakan. J. Fac. Sci., Hakkaido Univ., Ser. VII (Geophys.) 8-5, 465-477.

Minsley, B.J., Sogade, J., Morgan, F.D., 2007. Three-dimensional self-potential inversion for subsurface DNAPL contaminant detection at the Savannah River Site, South Carolina. Water Resour. Res. 43, W04429. doi:10.1029/2005WR003996.

Moore, J., Glaser, S.D., 2004. Laboratory observations of an advancing boiling front in a porous medium and correlation to self potential measurements. Proceedings, 29th Stanford Workshop on Geothermal Reservoir Engineering.

Moore, J.R., Glaser, S.D., 2007. Self-potential observations during hydraulic fracturing. J. Geophys. Res. 112, B02204. doi:10.1029/2006JB004373.

Nishida, Y., Tomiya, H., 1987. Self-potential studies in volcanic areas - Usu volcano. J. Fac. Sci., Hokkaido Univ., Ser. VII. Geophysics 8-2, 173-190.

Nishida, Y., Matsushima, N., Goto, A., Nakayama, Y., Oyamada, A., Utsugi, M., Oshima, H., 1996. Self-potential studies in volcanic areas (3) Miyake-jima, Esan and Usu. J. Fac. Sci., Hokkaido Univ. Ser. VII (Geophys.) 10, 63-77.

Nourbehecht, B., 1963. Irreversible thermodynamic effects in inhomogeneous media and their applications in certain geoelectric problems. Ph.D. Thesis, Mass. Inst. Of Technology, Cambridge.

Overbeek, J.T.G., 1952. Electrochemistry of the double layer. In: Kruyt, H.R. (Ed.), Colloid Science. : Irreversible Systems, vol. 1. Elsevier Sci, New York, pp. 115-193.

Peltier, A., 2007. Suivi, modélisation et évolution des processus d'injections magmatiques au Piton de La Fournaise (Réunion) à partir d'une analyse croisée des données de déformation, géochimiques et structurales. Ph.D. Thesis, Univ. La Réunion, 345 pp.

Pokrovsky, O., Schott, J., Thomas, F., 1999. Processes at the magnesium bearing carbonates-solution interface: I A surface speciation model for magnesite. Geochim. Cosmochim. Acta 63, 863-880.

Revil, A., 1995. Conductivité Electrique et Potentiel Spontané dans les Mileux Poreux : De la Théorie à l'Analyse des Mesures en Forage, Ph-D Thesis, Université Louis Pasteur à Strasbourg (in french).

Revil, A., 1999. Ionic diffusivity, electrical conductivity, membrane and thermoelectric potentials in colloids and granular porous media: a unified model. J. Colloid Interf. Sci. 212, 503-522.

Revil, A., 2002. Comment on "Rapid fluid disruption: a source for self-potential anomalies on volcanoesa" by M. J. S. Johnston, J. D. Byerlee, and D. Lockner. J. Geophys. Res. 107 (B8). doi:10.1029/2001JB000788

Revil, A., Cerepi, A., 2004. Streaming potential in two-phase flow condition. Geophys. Res. Lett. 31 (11), L11605 doi:1029/2004GL020140, 2004

Revil, A., Linde, N., 2006. Chemico-electromechanical coupling in microporous media. J. Colloid Interf. Sci. 302, 682-694.

Revil, A., Pezard, P.A., 1998. Streaming potential anomaly along faults in geothermal areas. Geophys. Res. Lett. 25 (16), 3197-3200.

Revil, A., Schwaeger, H., Cathles, L.M., Manhardt, P., 1999. Streaming potential in porous media. 2. Theory and application to geothermal systems. J. Geophys. Res. 104 (B9), 20,033-20,048.

Revil, A., Hermitte, D., Spangenberg, E., Cochémé, J.J., 2002. Electrical properties of zeolitized volcaniclastic materials. J. Geophys. Res. 107 (B8), 2168. doi:10.1029/ 2001JB000599.

Revil, A., Saracco, G., Labazuy, P., 2003. The volcano-electric effect. J. Geophys. Res. 108 (B5), 2251. doi:10.1029/2002JB001835.

Revil, A., Finizola, A., Sortino, F., Ripepe, M., 2004. Geophysical investigations at Stromboli volcano, Italy. Implications for ground water flow and paroxysmal activity. Geophys. J. Intern. 157, 426-440. doi:10.1111/j.1365-246X.2004.02181.x.

Revil, A., Linde, N., Cerepi, A., Jougnot, D., Matthäi, S., Finsterle, S., 2007. Electrokinetic coupling in unsaturated porous media. J. Colloid Interface Sci. 313 (1), 315-327. doi:10.1016/j.jcis.2007.03.037. 
Rizzo, E., Suski, B., Revil, A., Straface, S., Troisi, S., 2004. Self-potential signals associated with pumping-tests experiments. J. Geophys. Res. 109, B10203. doi:10.1029/ 2004JB003049.

Sato, M., Mooney, H.M., 1960. The electrochemical mechanism of sulphide self potentials. Geophysics 35, 226-249.

Sill, W.R., 1983. Self-potential modeling from primary flows. Geophysics 48, 76-86.

Trique, M., Perrier, F., Froidefond, T., Avouac, J.-P., Hautot, S., 2002. Fluid flow near reservoir lakes inferred from the spatial and temporal analysis of the electric potential. J. Geophys. Res. 107. doi:10.1029/2001JB000482.
Zablocki, C.J., 1976. Mapping thermal anomalies on an active volcano by the selfpotential method, Kilauea, Hawaii. Proceedings, 2nd U.N. Symposium on the Development and Use of Geothermal Resources, San Francisco, California, May 1975, vol. 2, pp. 1299-1309.

Zohdy, A.A.R., Anderson, L.A., Muffler, L.J.P., 1973. Resistivity, self-potential and induced polarization surveys of a vapour-dominated geothermal system. Geophysics 38 (6), 1130-1144. 